\title{
CAMK2G wt Allele
}

National Cancer Institute

\section{Source}

National Cancer Institute. CAMK2G wt Allele. NCI Thesaurus. Code C104834.

Human CAMK2 G wild-type allele is located in the vicinity of 10q22 and is approximately $62 \mathrm{~kb}$ in length. This allele, which encodes calcium/calmodulin-dependent protein kinase type II subunit gamma protein, plays a role in calcium signaling. 